Abstracta Iranica Abstracta Iranica

Revue bibliographique pour le domaine irano-aryen

Volume 24 | 2003

Comptes rendus des publications de 2001

\title{
Jaryān-e por-šetāb-e TTălebān [The rapid Process of Taliban]. Tehrān, Alhodā, 1999, 311 p.
}

\section{Tchanguiz Pahlavan}

\section{(2) OpenEdition}

1 Journals

\section{Édition électronique}

URL : http://journals.openedition.org/abstractairanica/34915

DOI : 10.4000/abstractairanica.34915

ISSN : 1961-960X

Éditeur:

CNRS (UMR 7528 Mondes iraniens et indiens), Éditions de l'IFRI

\section{Édition imprimée}

Date de publication : 15 mai 2003

ISSN : 0240-8910

\section{Référence électronique}

Tchanguiz Pahlavan, « Jaryān-e por-šetāb-e Țālebān [The rapid Process of Taliban]. Tehrān, Alhodā, 1999, 311 p. », Abstracta Iranica [En ligne], Volume 24 | 2003, document 338, mis en ligne le 05 janvier 2010, consulté le 25 septembre 2020. URL : http://journals.openedition.org/abstractairanica/34915 ; DOI : https://doi.org/10.4000/abstractairanica.34915

Ce document a été généré automatiquement le 25 septembre 2020.

Tous droits réservés 


\title{
Jaryān-e por-šetāb-e Ṭālebān [The rapid Process of Taliban]. Tehrān, Alhodā, 1999, 311 p.
}

\author{
Tchanguiz Pahlavan
}

1 Five authors of Afghanistan (M. Ḥ. 'Eșmatollāhī, W. Bīneš, M. Qāsem, D. BaH̆tiyārī, M. A. 'Aẓīmī, M. Kābolī) are presenting in this book the result of a common research about the rise of Taliban. The book is divided in four chapters. The first one deals with the ethnic structure of the Taliban, their religious and political views. The second chapter is devoted to the historical backgrounds of the formation of the Taliban. In the third chapter the authors deal with the practical aspects of the Taliban rule in Afghanistan.

2 Fourth chapter is devoted to the international relations of the Taliban rule and various aspects of their foreign policy.

3 This book is actually reflecting a number of information collected from different sources.

\section{INDEX}

Thèmes : 13.2. Afghanistan 


\section{AUTEURS}

TCHANGUIZ PAHLAVAN

Berlin 